\title{
A Diversification Strategy for Perennial Horticulture in Florida
}

\author{
Kimberly L. Morgan ${ }^{1}$ and Mercy A. Olmstead ${ }^{2,3}$
}

\begin{abstract}
ADDITIONAL INDEX WORDs. citrus, grower survey, market price, orchard establishment, peach, terminal price

SUMMARY. Florida has a large and diverse horticulture industry, with large quantities of fruit and vegetables produced from November to February. Diversification strategies have come to the forefront in perennial horticulture sectors, such as citrus (Citrus sp.), where several diseases have reduced productivity and acreage. Many growers are considering diversification of their groves to other fruit crops, such as peach (Prunus persica). To understand the state of the industry and provide perspective for transitional Florida growers to mitigate risk, a survey was conducted in 2011. A total of 27 completed survey questionnaires were returned which represented $68 \%$ of 2011 Florida peach orchard owners and managers. On average, responding peach orchard size was 18 acres, ranging from 1 to 100 acres, with 'TropicBeauty', 'UFSun', 'UFOne', and 'UFBeauty' comprising the main varieties. Production and marketing challenges were key issues identified by growers as they sought to mitigate risk in an uncertain economic climate. Key sources of production information were university personnel, followed by fellow growers, indicating that stone fruit (Prunus sp.) extension programs are effective in information delivery. Tree production expertise combined with geographic proximity to concentrated market segments, access to established fresh fruit distribution routes, and existing relationships with retail market customers are expected to provide the Florida treeripened peach grower with unique marketing opportunities. Findings from this survey effort will be used by the project team to develop educational materials and outreach programs, designed to better address the production and marketing risks facing Florida peach growers. In addition, project results will provide new in-

formation for regional and national perennial crop producers who are interested in diversifying production practices to meet increased consumer demand for access to locally sourced horticultural products.
\end{abstract}

$\mathrm{F}$ lorida has a diverse horticultural industry, second only to California in terms of crop variety and production volume within the United States [U.S. Department of Agriculture (USDA), 2007]. Ideal growing conditions during the winter months allow growers to produce vegetables, citrus, and other fruit crops for fresh market distribution throughout the eastern United States. However, declines in productivity due to citrus greening (huanglongbing), citrus black spot (Guignardia citricarpa), and bacterial canker (Xanthomonas axonopodis pv. citri) (Chung et al., 2009; Dewdney

\footnotetext{
This research was supported by the Florida Department of Agriculture and Consumer Services Specialty Crop Block Grant no. 2010-0016867 from the USDA National Institute of Food and Agriculture.

The authors would also like to thank the members of the Florida stone fruit industry for their survey participation and initial review of the article.

${ }^{1}$ Department of Agricultural Economics, Mississippi State University, P.O. Box 5187, Mississippi State, MS 39762

${ }^{2}$ Horticultural Sciences Department, University of Florida, P.O. Box 110690, Gainesville, FL 32611

${ }^{3}$ Corresponding author. E-mail: mercyl@ufl.edu.
}

and Peres, 2012; Morris and Muraro, 2008; Schubert and Sun, 2003) have motivated Florida citrus growers to seek alternative investments with the potential to replace citrus groves affected by these diseases. One risk management strategy receiving consideration by the Florida tree industry is peach production.

Nationwide, 149,237 acres of peach were managed on 13,582 operations (USDA, 2007). During the 1960s and 1970s, Florida peach acreage reached an estimated 3900 acres, providing the eastern U.S. market with the first domestic source of peaches. However, a series of freeze events in the 1980 s, coupled with poor freeze protection systems and marketing challenges reduced total peach acreage to fewer than 300 with an average size of 1.6 acres (Ferguson et al., 2006; USDA, 2007). These numbers are very low when compared with Georgia, the largest peach-growing state in the eastern United States, with a total of 12,356 acres located on 279 operations with an average farm size of 44.3 acres (USDA, 2007). States for which acreage statistics are collected (i.e., Alabama, SC) that have early marketing potential for fresh peaches have exhibited increased acreage from 2010 to 2012 , in spite of continued declines in nationwide peach acreage (USDA, 2013a). Steady improvement in varieties released by the Florida stone fruit breeding program of low chill, nonmelting flesh varieties combined with the shift of main growing areas to central and south-central Florida have generated additional interest in peach production.

In 2008, a Florida Market Improvement Project Study found that 7700-10,400 acres would be required to satisfy consumer and market demands as the Florida peach industry expands into the eastern United States (Harrison et al., 2008). The study found that $76.6 \%$ of Florida consumers surveyed would be willing to pay more for tree-ripened peaches, and $43.3 \%$ rated the Florida peach samples tested as the best (Harrison et al., 2008). Recent releases from the University of Florida (UF) peach breeding program have focused on nonmelting, firmer flesh peaches possess comparable flavor attributes, despite the textural differences from nonmelting flesh varieties (Brovelli et al., 1995). Because of their firmer texture, these nonmelting flesh varieties are harvested at a riper stage than melting flesh varieties, leading to an increase in the soluble sugar content and reduced titratable acidity, longer shelf life, and ability to market these nonmelting varieties as "tree-ripe" (Kao et al., 2012). In addition, two nonmelting flesh varieties exhibited lower sensitivity to chilling injury, which has been implicated in the development of "mealiness," "wooliness," or both in the peach flesh (Brovelli et al., 1998; Crisosto, 2002). These attributes have led to higher consumer acceptance of tree-ripened nonmelting peaches compared with melting flesh peaches when flavor, juiciness, texture, appearance,

\begin{tabular}{llll}
\hline $\begin{array}{l}\text { Units } \\
\text { To convert U.S. to SI, } \\
\text { multiply by }\end{array}$ & U.S. unit & SI unit & $\begin{array}{l}\text { To convert SI to U.S., } \\
\text { multiply by }\end{array}$ \\
\hline 0.4047 & acre(s) & ha & 2.4711
\end{tabular}


and overall quality were examined (Williamson and Sargent, 1999). Improvements in peach quality and extension of shelf life with nonmelting varieties, combined with rising demand for locally sourced produce, have the potential to increase domestic peach consumption of tree-ripened Florida-grown peaches.

Growers in Florida are poised to take advantage of a unique marketing opportunity for tree-ripened peach production. Producers in central and south-central Florida are able to provide product to the fresh market during early April through late May, targeting a market window with declining peach imports from South America and before domestic product from California is available (Fig. 1) (USDA, 2012). Nationwide, peach growers with available product during periods when product is normally imported are best positioned to command higher prices (Fig. 1). As the growing season progresses, monthly average prices received by U.S. growers decline, making it less profitable for Florida growers to market and sell their fruit during peak production months of May through July (Fig. 2) (USDA, 2013b). Currently, growers in Florida reported farm gate prices received that ranged from $\$ 1.75 / \mathrm{lb}$ to $\$ 2.00 / \mathrm{lb}$ for their tree-ripened peaches (M.A. Olmstead, unpublished data), compared with peak season average terminal prices of $\$ 0.70 / \mathrm{lb}$ (USDA $2013 \mathrm{~b}$ ) and season-wide prices of $\$ 0.4 \mathrm{l} / \mathrm{lb}$ received by U.S. growers in 2011 (USDA, 2013c). Current Florida peach volume estimates range from 3 to 4 million pounds of fruit marketed (M.A. Olmstead, unpublished

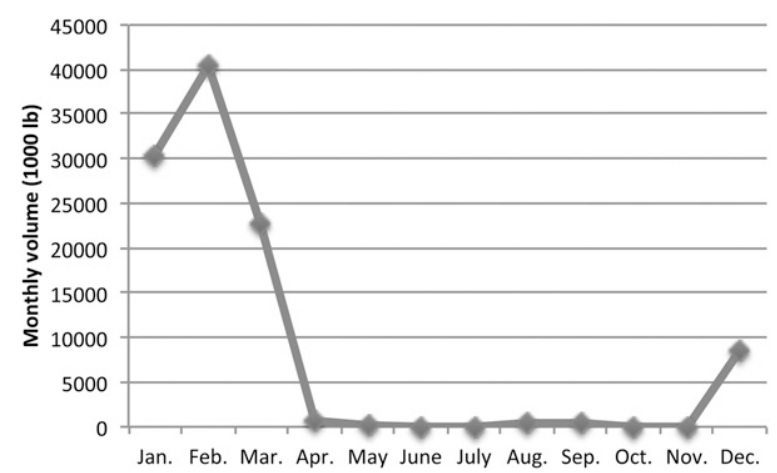

Fig. 1. Average monthly fresh market U.S. imported peach and nectarine volume (1000 lb per month), 2011. Countries supplying the majority of imported produce are Chile and Canada; $1 \mathrm{lb}=0.4536 \mathrm{~kg}$. data), with upwards of 5 million pounds expected to hit the market due to newly established orchards reaching maximum production capacity.

In an effort to mitigate production and marketing risks faced by current and potential growers seeking to diversify their operations, members of the Florida tree industry requested the project team provide an assessment of the current state of the Florida peach industry. Upon clarifying collaborator needs with input from an advisory panel of Florida peach orchard owners and managers, the authors conducted an exploratory survey in 2011. Survey questions included sections related to grower demographics, orchard acreage, peach production practices, current and future risk preferences and strategies, market channel selection and satisfaction levels, trusted information sources, and needed research and education topics.

The project team intends to use results from individual grower interviews and the online survey to quantify existing production and marketing decisions made by current Florida peach orchard managers, to gauge interest in peach crop insurance, and to understand adoption of alternative technologies. Topics of concern to Florida orchardists were identified and used to inform development of risk management materials and educational events related to peach production and marketing. Survey findings and outreach materials are expected to provide

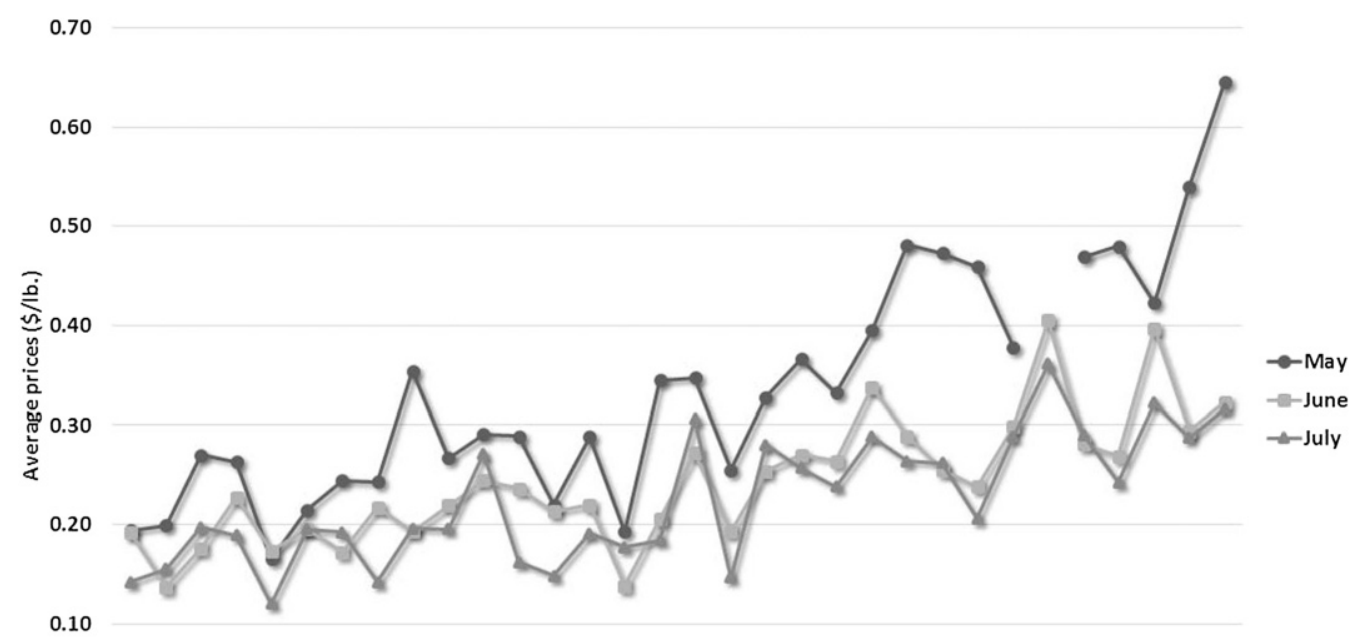

0.00

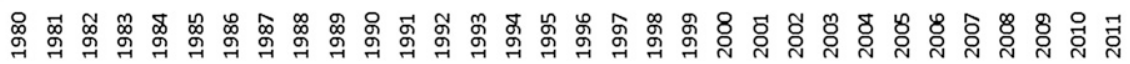

Fig. 2. Average farm-gate prices received by U.S. growers for fresh peach marketed during peak production seasons, May-June $(1980-2012) ; \$ 1.00 / 1 \mathrm{~b}=\$ 2.2046 / \mathrm{kg}$. 
timely best management practices for Florida peach orchardists to mitigate production risks related to adoption of new perennial stone fruit crops. It is anticipated that improved grower awareness of historical and current market price trends, and region-specific consumer demand characteristics for fresh, tree-ripened peaches will minimize market risk exposure and result in long-term sustainability of the Florida peach industry.

\section{Materials and methods}

To determine the current production and marketing practices of the Florida peach industry, independent interviews of key growers in six major growing regions were conducted by the authors in June 2011: Dade City and Dundee (central Florida), Sebring and Port Charlotte (southcentral Florida), Fort Pierce and Hastings (eastern Florida) $(\mathrm{N}=18)$. Findings of these initial interviews were used to guide the development of our peach grower survey instrument. Following Mississippi State University (MSU) Human Research Protection Protocol OP 79.03 (MSU, 2009), the survey instrument was reviewed and received approval from the MSU Institutional Review Board to ensure protection and privacy of participants throughout the survey process. As the Florida peach industry is newly formed and comprises independent growers with no formal membership or association, the target population of 40 known Florida peach operation owners and managers was identified by UF/ Institute of Food and Agricultural Sciences (IFAS) extension personnel. Following Dillman et al. (2008), the survey questionnaires were provided via mailed and e-mailed paper copy, and offered online via a secure server accessible only by invitation to maximize grower response rates. A total of 25 questions were asked, including respondent demographics; years' orchard experience; orchard characteristics such as acreage owned, leased, or both, varieties planted, and technologies used; marketing channels; preferred information sources; crop insurance purchases; manager relative price risk preferences; and 2011 gross income specific to peach orchard, other farm income, and off-farm income sources. Sample selection of the survey questions is shown in Fig. 3. The survey questionnaire was available from 15 June through 31 Dec. 2011. The authors recruited respondents via e-mail, personal phone calls, and invitations issued during peach grower meetings. Survey response data were aggregated for reporting purposes and to ensure respondent confidentiality.

\section{Results and discussion}

Completed questionnaires were received from a total of 27 Florida peach orchard owners and managers representing a total response rate of
$68 \%$ of the 2011 Florida peach industry. Of the 27 total respondents, three noted that they had not yet produced commercially marketable fruit due to grove immaturity. Seventy-three percent $(n=20)$ of the survey participants had completed at least one college degree and were at least 45 years of age. Participants managed a total of 630 acres in Florida peach production, of which $76 \%$ and $24 \%$ were owned or leased, respectively (Table 1). Our survey results revealed that peach

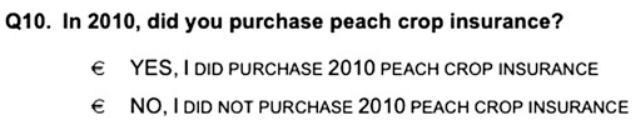

Q11. How likely are you to CONSIDER purchasing peach crop insurance in the NEXT FIVE years? Please circle the number indicating your likelihood:

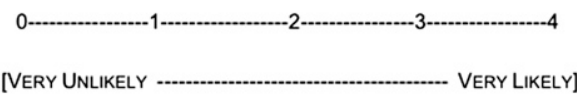

Q12. For 2011, please indicate the percentage of your peach production you sold through each of the marketing channels. Check that your responses total $100 \%$ of your total 2011 peach sales.

\begin{tabular}{ll}
2011 PEACH SALES & PERCENT OF TOTAL 2011 SALES \\
\hline 2011 SALES TO COOPERATIVE $\ldots \ldots \ldots \ldots \ldots \ldots \ldots \ldots \ldots \ldots \ldots \ldots$ & \\
2011 SALES TO WHOLESALER (BROKER) $\ldots \ldots \ldots \ldots \ldots \ldots$ & PERCENT \\
2011 SALES DIRECT TO FINAL CUSTOMER $\ldots \ldots \ldots \ldots \ldots \ldots$ & PERCENT \\
\hline
\end{tabular}

Q13.Thinking about each of these same marketing channels, how satisfied or dissatisfied were you with each channel that you used in 2011? Circle your level of satisfaction with each marketing channel that you used in 2011.

\begin{tabular}{lccc}
2011 MARKETING CHANNEL & \multicolumn{3}{c}{ HOW SATISFIED? (PLEASE CIRCLE) } \\
\hline COOPERATIVE & NOT & SOMEWHAT & VERY \\
WHOLESALER (BROKER) & NOT & SOMEWHAT & VERY \\
DIRECT TO FINAL CONSUMER & NOT & SOMEWHAT & VERY \\
\hline
\end{tabular}

Q14.Relative to other peach growers, how would you describe your willingness to accep RISK in your peach farm business? Circle the number that best represents your answer.

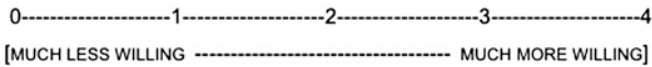

Q15. Relative to other peach growers, how concerned are you about AVERAGE peach prices during 2012 season? Circle the number that best represents your answer.

[MUCH LESS CONCERNED

Fig. 3. Sample survey questions from the full survey instrument distributed from 15 June through 31 Dec. 2011 to Florida peach orchard owners and managers.

Table 1. Comparison of Florida peach orchard acreage in production recorded by the 2007 Census of Agriculture (USDA, 2007) to those reported by 2011 Florida peach grower survey respondents.

\begin{tabular}{lccccc}
\hline \multicolumn{2}{c}{$\begin{array}{c}2011 \text { Florida peach } \\
\text { grower survey }\end{array}$} & \multicolumn{2}{c}{$\begin{array}{c}\text { 2007 Census } \\
\text { of agriculture }\end{array}$} & \\
\cline { 5 - 6 } No. of farms & Acres $^{\mathrm{y}}$ & & No. of farms & Acres & Change in acreage \% \\
\hline 24 & 630 & & 145 & 234 & $+169 \%$ \\
\hline
\end{tabular}

${ }^{\mathrm{z}}$ Of the 27 total survey respondents, three did not have commercially marketable fruit in 2011 but had acquired (or were planning to purchase or lease) peach orchards in the immediate future. Of the 2011 survey respondent peach orchard acreage, $154(24 \%)$ acres were leased.

y 1 acre $=0.4047$ ha 
acreage in the state had increased by 169\% since the 2007 Census of Agriculture, with orchard sizes ranging from 1 to 100 total acres for an average of 18 acres per grower. It is expected that the 2012 Census of Agriculture will further support an increase in peach acreage within Florida. Since the end of the survey period, the authors were notified that another 300 acres were planted in 2012, which are not reflected in these reported survey results.

Seventy percent $(n=19)$ provided information about the sources of their 2011 family income. Respondents indicated that off-farm income accounted for an average of $59 \%$ of total family income, on-farm income from all crops averaged 39\% and the remaining two percent was generated solely from peach production efforts. Overall, $70 \%(n=19)$ of the respondents indicated that both their peach land and establishment costs were not financed in 2010. One grower responded that about one-quarter of the peach operation was financed, while three other growers leveraged about half of their 2010 operations.

As expected, given the newness of the Florida peach industry and the southward shift in location of the orchards, survey respondents had an average of just 2 years' experience in growing peach trees. Seven (26\%) indicated that they had acquired new land since 2005 to establish orchards. The varieties reported by growers included both melting (e.g., Tropic Beauty, Flordaprince) and nonmelting type flesh peaches (e.g., UFSun, UFOne, UFBeauty). These reported varietal preferences are typical of staggered orchard production which utilizes multiple varieties with differing ripening periods, a practice that allows growers to provide a steady supply of fresh produce to the broker or final customer (i.e., wholesalers or grocery stores) over a longer time period. The majority $(84 \%)$ of respondents who reported 2011 peach operation gross sales were categorized in the "under \$49,999" range, with three reporting annual gross sales in the $\$ 50,000$ to $\$ 249,999$ range.

Particularly for newer growers, availability of trusted information sources is a key component to production viability and profitability. While survey participants were recruited by university personnel, respondents confirmed that extension and outreach personnel are best positioned to aid growers in optimizing peach business practices with the goal of maximizing profitability. The vast majority of growers $(89 \%)$ indicated that university personnel and other peach growers were equally valued (Fig. 4). Eighteen respondents $(67 \%)$ indicated they used information provided on the Internet, and specified sourced materials on websites hosted by UF-IFAS, Florida Department of Agricultural and Consumer Sciences, Clemson University, and University of Georgia. Currently, there are no grower associations established specifically by Florida producers, although one respondent indicated that $\mathrm{s} /$ he attended neighboring state grower association meetings. Growers were asked to indicate the top three information sources used, and 13 respondents $(48 \%)$ placed university personnel as "most important" and another four (15\%) selected "other growers" in this category.

Rising consumer awareness of the associated health benefits of fresh fruit consumption (Pollack, 2001), a nationwide increase of $43 \%$ in per capita consumption of fresh noncitrus fruit between 1970-79 and 2000 (USDA, 2003) and expanding interest in purchasing locally sourced produce particularly among urban populations (Brown, 2003; Low and Vogel, 2011; Maples et al., 2013; Onken et al., 2011; Zepeda and Leviten-Reid, 2004), combined with documented market preferences for tree-ripened fruit (Harrison et al., 2008; Williamson and Sargent, 1999), provide a unique marketing

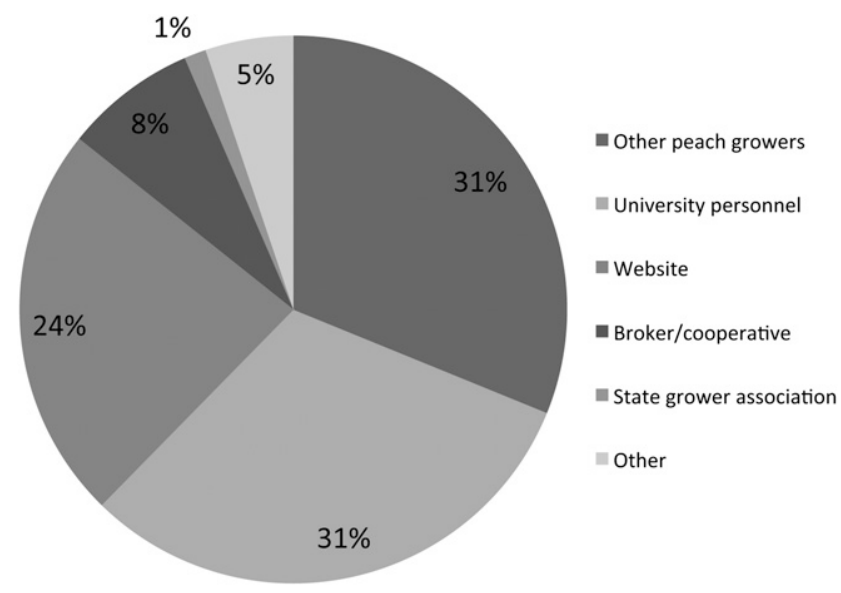

Fig. 4. Information sources used by Florida peach growers using various information sources for peach production and marketing research. The percentages indicate percent of total survey respondents $(\mathrm{N}=27)$. dustry. A Florida local foods consumer survey (Hodges and Stevens, 2013) revealed that local foods represented $20 \%$ of total food purchases for at-home consumption, with fresh local fruit purchases exceeding $\$ 1.5$ million in 2011-12, representing the second largest food category behind vegetables. Peach growers seeking to meet this demand in an effort to command larger percentages of the consumer food dollar, of which farm shares typically hover around $\$ 0.155$, must invest time and financial resources in the development and implementation of a firm marketing plan. Florida peach growers have a potential direct market advantage due to their product reaching consumers before peak U.S. production period, yet revenue estimates will depend on accurate pricing and successful market development (Curtis et al., 2012). Research aimed at understanding which markets, products, attributes, etc. are significantly related to the probability of consumers purchasing direct from growers is on-going (Bond et al., 2009; Brown, 2003; Thilmany et al., 2008; Zepeda and Li, 2006). In an effort to understand the market channel preferences for existing Florida peach growers, respondents were asked to indicate their marketing channel selections used during the 2011 season. Respondents provided information on their peach marketing programs for 2011 production $[\mathrm{N}=13(48 \%)$ ], which was sold through one or more available marketing channels, including cooperative, wholesale/broker, and opportunity for the Florida peach in- 
direct-to-final consumer sales. Seventy percent $(\mathrm{N}=9)$ of respondents sold their peaches as direct-to-consumer sales, five $(38 \%)$ sold fresh peaches via a cooperative arrangement, and just two (15\%) sold through wholesale/ broker intermediaries. On average, direct-to-consumer sales accounted for the majority $(78 \%)$ of these respondent total sales volumes and were produced on 215 (45\%) owned acres. Peach growers that sold via cooperatives reported nearly all (97\%) of their fresh peach volumes were distributed through this market channel, representing $85(18 \%)$ total owned acres. Growers were asked to rate their level of satisfaction with their current marketing channel. Nearly all $(78 \%)$ direct-to-consumer channel participants were "very satisfied," while two $(15 \%)$ indicated they were "somewhat satisfied."

Perennial orchard production is a relatively higher risk farming activity, with planting year establishment costs estimated to exceed $\$ 5000$ per acre and a minimum of 3 years required for trees to reach full production potential. When making a decision to invest in new varieties, additional orchard acreage, or both, grower perceptions of risks related to both production and market prices for that industry are critically important (Dyer and Sarin, 1982; Hudson and Lusk, 2004; Pennings and Garcia, 2001). To develop an understanding of the risk perceptions of Florida peach growers, respondents were asked to indicate their individual willingness to accept risks related specifically to their peach operation. Growers provided a median rating of 3 on a five-point Likert scale, where " 0 " indicated that grower was "much less willing to accept risk" and a " 4 " indicated that grower was "much more willing to accept risk" relative to another peach grower. Fifty-two percent $(\mathrm{n}=14)$ of growers rated their willingness to accept risk as either "more willing" or "much more willing" as compared with other peach growers, with an additional 11 growers $(41 \%)$ placing themselves at the midpoint (Likert scale $=2$ ). Using a five-point Likert scale, where " 0 " indicated "much less concerned" and " 4 " indicated "much more concerned," respondents revealed a median rating of 3.0 when asked how concerned they were about average peach prices for the upcoming 2012 season relative to other peach growers. A total of 18 growers (67\%) indicated they were either "more concerned" or "much more concerned" about 2012 peach prices relative to other peach growers, with another five $(19 \%)$ indicating a midpoint (Likert score $=2$ ) concern level. A final risk acceptance question asked respondents how concerned they were about the stability and variation of peach prices for the 2012 season, and the median Likert rating was 3 , where "0" equaled "much less concerned" and " 4 " was equivalent to "much more concerned" relative to other peach growers. With respect to the concern about 2012 peach price stability and variation, a total of 16 respondents (59\%) selected either "more concerned" or "much more concerned" relative to their fellow peach growers, and another nine (33\%) indicated a midpoint (Likert score $=2$ ) level of concern. To determine the relationship, if any, between peach orchard size and owner/manager relative risk perceptions, average Likert scores were examined for operations with less than or equal to 10 acres and those with more than 10 acres. Fourteen growers with more than 10 acres in 2011 production reported higher willingness to accept all types of risk, and relatively higher levels of concern about future average price variability and price stability, averaging 4.1 on a five-point Likert scale for all three questions. Risk acceptance and price concerns were closer to neutral levels for the 12 smaller ( $\leq 10$ acres) peach operations, averaging 3.3 (on fivepoint scale) for both willingness to accept risk and level of concern with price stability, and 3.4 (on five-point scale) for level of concern about future average peach prices. Responses to the price risk survey questions regarding farm gate price stability and variation specifically referenced the upcoming production season, yet these concerns were expected to influence manager decision-making related to the long-term profitability of an existing or potential orchard operation.

The availability of crop insurance is a key component in mitigating risk for peach producers due to the variability in spring temperatures and frost events that can severely reduce crop potential. Specialty crop producers and U.S. Congressional members are cooperating to enhance crop insurance availability for specialty crops (Shields, 2012). In Florida, only one county had crop insurance programs available to growers in 2010 , which is the most likely reason for limited number of respondents (three) that indicated they had purchased crop insurance. Furthermore, this county was removed from the crop insurance program in 2012 (J. Lindsey, personal communication). The strong demand for peach crop insurance in Florida was evident as $77 \%$ of respondents $(\mathrm{n}=$ 21) indicated they were somewhat likely to purchase crop insurance in the next 5 years, if available. This demonstrated grower need for development of Florida peach crop insurance programs as a production risk management tool has been communicated to the USDA Risk Management Agency [RMA (administers the Federal Crop Insurance Corp., Washington, DC)]. Future research related to determination of peach orchard insurance costs, coverage levels, and crop damage assessment rules is recommended to provide accurate assessments of grower adoption of crop insurance products (Richards, 2000; Sherrick et al., 2003).

Research related to understanding those factors positively correlated to grower adoption of production and marketing practices such as crop diversity, integrated pest management techniques, and risk management potential has revealed the importance of previous technology adoption behavior of growers (Cutforth et al., 2001; Lowenberg-DeBoer, 1998; Paxton et al., 2011). To develop an understanding of this relationship, survey participants were asked about technologies currently in use or planned for future implementation in their peach orchards. Twenty-four $(89 \%)$ submitted samples for soil analysis, 12 $(44 \%)$ conducted plant leaf analysis, and $10(37 \%)$ used some sort of freeze protection during 2011. Ten respondents (37\%) used drip-tape, microjet, or macrojet irrigation systems and another two $(7 \%)$ used overhead irrigation, with a total of $12(44 \%)$ reported investments in some type of irrigation system for their peach orchards. When asked about future investments in these same technologies in the next 5 years, nine growers $(33 \%)$ indicated that they would be installing freeze protection, and three $(11 \%)$ each indicated they plan to implement overhead irrigation and plant leaf analysis, all of which represent much-needed investments in infrastructure and production risk 
minimization techniques as recommended by specialists (Ferguson et al., 2007).

Implementation of best management practices (BMPs), especially to reduce nutrient leaching, has received much attention in Florida as a means to comply with increased water quality regulations imposed by the U.S. Environmental Protection Agency. Twenty-two (81\%) respondents answered questions related to their implementation of BMPs regarding fertilizer application, including formulation and type of application (granular, liquid fertilization via fertigation, or a combination). Forty-six percent $(n=10)$ of growers applied both granular and liquid fertilizer, while four (18\%) growers applied only granular fertilizer and another five (23\%) growers only liquid applications. A range of fertilizer formulations were reported from those with no phosphorus content $[21 \mathrm{~N}-0 \mathrm{P}-1.7 \mathrm{~K}$ (data not shown)] applied via granular application to liquid formulations of $9 \mathrm{~N}-3.6 \mathrm{P}-7.5 \mathrm{~K}$ that were part of a weekly fertigation program, indicating a clear need for research and education as BMP recommendations prescribe a balanced
$10 \mathrm{~N}-4.4 \mathrm{P}-8.3 \mathrm{~K}$ formulation for loamy soils or $12 \mathrm{~N}-1.7 \mathrm{P}-6.6 \mathrm{~K}$ for sandy soils (Ferguson et al., 2007). An encouraging finding is the $79 \%$ $(\mathrm{n}=17)$ of respondents who used fertigation for all or part of their annual application of fertilizer, one of many recommendations to maximize water quality in agricultural operations (Florida Department of Agriculture and Consumer Services, 2011). In addition, several respondents reported efficient fertilizer applications in combination with soil testing, tissue testing, or both, which indicates that growers are complying with and implementing BMPs as new orchards are established.

Respondents were asked to indicate their priority ranking from a list of potential future research priorities for the Florida peach industry (Fig. 5). Specifically, peach growers placed higher priority on insect control, concern about consumer demand, and the need for fertilization protocols, disease and fungal control measures, and low chill peach variety development (as specified in "other" category in Fig. 5). The "medium" tier of priorities included food safety regulations, weed control and management, labor regulations, and availability of crop insurance for those Florida counties where peach production acreage has been recently established. Although important, government regulations were placed in a relatively lower priority category. The emphasis areas suggest future research and educational areas that can be met by university research and extension faculty. As an example, specialists were invited to the 2012 and 2013 Florida peach grower workshops and presented information related to national farm gate price trends, peach pathology, orchard weed management, variety reports, planning budgets for peach enterprises, etc.

\section{Summary and implications}

Overall, the majority of survey participants rated themselves as more willing to accept the risks associated with peach production in Florida relative to their fellow orchardists, which provides insight into their decisions to seek out a feasible risk management strategy in response to continued disease pressures facing citrus orchard managers. Growers in the citrus industry

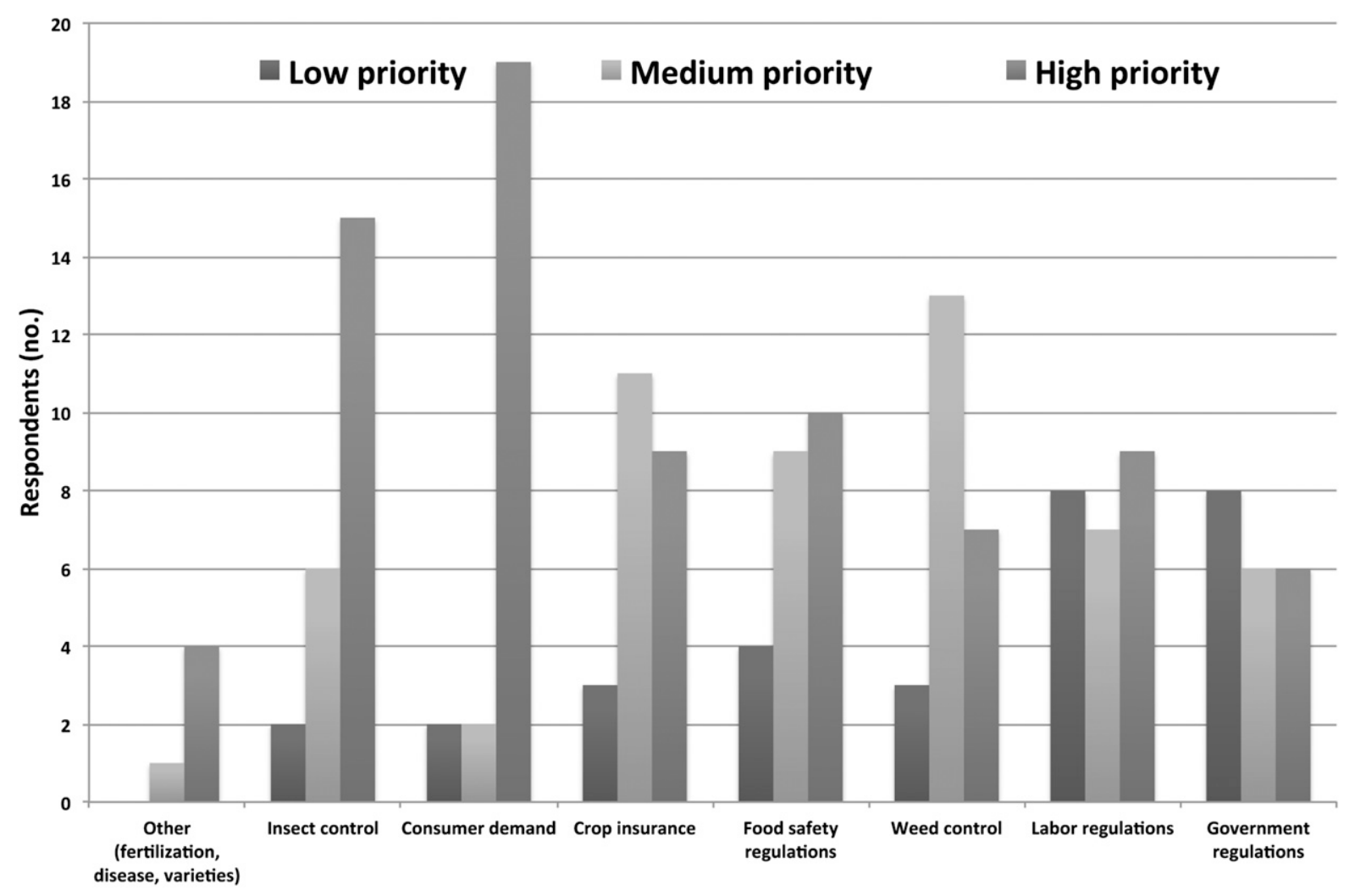

Fig. 5. Number of respondents who indicated priority levels for suggested future research goals of concern to the Florida peach industry. Respondents were asked: "how much priority, if any, should each goal have for future research priority?" and allowed to assess each issue independently with a low, medium, or high priority designation. 
are seeking to diversify their operations and capitalize on owned orchard land and existing relationships with packing sheds and direct-from-grower buyers. As evidenced by reported Florida peach grower prices received, there is considerable potential in early season U.S. peach production given variety improvements and rising market demand for tree-ripe locally grown fruit. However, the relatively large difference between reported national and Florida average farm-gate prices indicate that growers must develop a clear understanding of locally sourced consumer demand characteristics with the goal of minimizing price risk exposure. Specifically, peach orchard managers need to engage in development of firm-level marketing strategies to include these objectives: 1) to build sustainable direct market relationships with cooperatives and retailers; 2) to assess feasible production capacity of the new varieties during the out-of-season market window; 3 ) to collect and use current and historical peach price data trends specific to their target markets; and 4) to consider infrastructure investments, such as refrigerated trucking and cold storage, to ensure access to distribution networks.

Education of new and transitioning growers about direct-to-consumer marketing, use of BMPs to market sustainably produced fruit, and implementation of diversified market channel sales strategies are of primary importance for long-term profitability of the Florida peach industry. Outreach programs designed to assist orchardists with identification of applicable marketing strategy components that focus on value-added product attributes (i.e., healthy, picked-fresh fruit grown locally), use of free promotional resources (i.e., Florida Market Maker, Fresh from Florida signage), implement accurate brand identification to promote and distinguish Florida peach fruit from other states' products, and expert analysis of daily national fresh fruit retail price trends are recommended. Delivery of relevant educational materials and information via timely technologies such as webinars, podcasts and social media outlets [e.g., YouTube (San Bruno, CA), Facebook (Palo Alto, CA), Twitter (San Francisco, CA), etc.] are critical, as out of-season growers are exposed to dramatic market price changes within 24-h time frames.
Finally, project implications are valuable to all regional and national perennial horticulture crop managers and their advisors, particularly those farm operators who intend to target markets where consumers are seeking to purchase products direct from growers. Land-grant extension experts have a long history of incorporating best production practices revealed by applied field research conducted on singleseason, monoculture, profit-maximizing enterprises; however, there is room for improvement in provision of expert analyses and appropriate communication of the dynamic domestic and international market and trade conditions facing perennial produce managers. Research continues to reveal significant motivational drivers underlying consumer demand for fresh fruit and vegetables sourced from a known farm and grown under transparent production practices, and long-term sustainability of perennial horticulture operations hinges on timely release of these findings. As perennial crop operations are characterized by high establishment costs and at least 3 years to reach maximum production, researchers and farm managers will benefit from a shared learning experience, which necessitates a continuous pattern of grower feedback throughout project implementation and evaluation. This project and its collaborators serve to exemplify one such effort to jointly engage experienced tree growers, multidisciplinary research and extension specialists, and a competitive funding agency program in the process of assessing a risk management diversification strategy.

In this report, new issues related to accurate identification and minimization of risks related to perennial horticulture diversification strategies were raised. Although based on a small sample size due to a growing peach industry, identification of these issues can be used to focus on specific topics for further studies. Our findings describe the characteristics of existing and new perennial specialty crop grower demand for perennial tree crop insurance products, a result that will be shared with USDA RMA personnel. Feedback from newer growers, in particular, emphasized the need for orchard enterprise planning budgets used by funding agencies interested in pursuing long-term investment opportunities in perennial horticultural operations. The project team has developed peach orchard cost and return estimates for the establishment year and each year of the tree's productive life for orchardists intending to secure operating funds from financial lenders (available at <http://hos. ufl.edu/sites/default/files/faculty/ maolmstead/documents/PeachBudget Worksheets24Junl3.xlsx >). Our findings suggest future research efforts should prioritize consumer demand research targeted toward our specialty crop growers who are engaged in direct-to-consumer market channels. Dissemination of objective, researchbased findings have the potential to increase grower understanding of rising consumer demand for fresh produce with nonprice attributes such as grower heterogeneity, traceability from seed to final edible food product, and adoption of production practices that aim to balance environmental costs, social costs, or both.

\section{Literature cited}

Bond, J.K., D.D. Thilmany, and C.A. Bond. 2009. What influences consumer choice of fresh produce purchase location? J. Agr. Appl. Econ. 41:61-74.

Brovelli, E.A., J.K. Brecht, W.B. Sherman, and C.A. Sims. 1995. Quality profile of fresh market melting and non-melting peach fruit. Proc. Florida State Hort. Soc. 108:309-311.

Brovelli, E.A., J.K. Brecht, W.B. Sherman, and C.A. Sims. 1998. Anatomical and physiological responses of melting- and nonmelting-flesh peaches to postharvest chilling. J. Amer. Soc. Hort. Sci. 123: 668-674.

Brown, C. 2003. Consumers' preferences for locally produced food: A study in southeast Missouri. Amer. J. Altern. Agr. 18:213-224.

Chung, K-R., N.A. Peres, and L.W. Timmer. 2009. Citrus diseases exotic to Florida: Black spot. Univ. Florida, Inst. Food Agr. Sci., Plant Pathol. Fact Sheet PP213.

Crisosto, C.H. 2002. How do we increase peach consumption? Acta Hort. 592: 601-605.

Curtis, K.R., I. Yeager, B. Black, and D. Drost. 2012. Potential benefits of extended season sales through direct markets. J. Food Distrib. Res. 43:113.

Cutforth, L.B., C.A. Francis, G.D. Lynne, D.A. Mortensen, and K.M. Eskridge. 2001. Factors affecting farmers' crop di- 
versity decisions: An integrated approach. Amer. J. Altern. Agr. 16(4):168-176.

Dewdney, M.M. and N.A. Peres. 2012. Citrus black spot. Univ. Florida, Inst. Food Agr. Sci., Dept. Plant Pathol. Fact Sheet PP274.

Dillman, D.A., G. Phelps, R. Tortora, K. Swift, J. Kohrell, J. Berk, and B.L. Messer. 2008. Response rate and measurement differences in mixed-mode surveys using mail, telephone, interactive voice response (IVR) and the Internet. Soc. Sci. Res. 38: $1-18$.

Dyer, J.S. and R.K. Sarin. 1982. Relative risk aversion. Mgt. Sci. 28:875-886.

Ferguson, J.J., J.X. Chaparro, D.M. O'Malley, and L. Harrison. 2006. Options for subtropical peach production in Florida. Proc. Florida State Hort. Soc. 119:29-31.

Ferguson, J., J. Chaparro, J.G. Williamson, R. Rouse, and R. Mizell. 2007. Florida subtropical peaches: Production practices. Univ. Florida, Inst. Food Agr. Sci. HS1109/HS348.

Florida Department of Agriculture and Consumer Services. 2011. Water quality/ quantity best management practices for Florida specialty fruit and nut crops. $25 \mathrm{Feb}$. 2013. <http://www.floridaagwaterpolicy. $\mathrm{com} /$ BestManagementPractices.html $>$.

Harrison, E.H., J.X. Chaparro, and L. Harrison. 2008. Sub-tropical peach market improvement project. Florida Dept. Agr. Consumer Serv., Div. Mktg. Dev., Tallahassee.

Hodges, A.W. and T.J. Stevens. 2013. Local food systems in Florida: Consumer characteristics and economic impacts. 3 June 2013. <http://www.fred.ifas.ufl.edu/ economic-impact-analysis/pdf/Floridastatewide-local-food-survey-2-6-13.pdf>.

Hudson, D. and J. Lusk. 2004. Risk and transactions cost in contracting: Results from a choice-based experiment. J. Agr. Food Ind. Organization 2(1):1-19.

Kao, M.-W.S., J.K. Brecht, J.G. Williamson, and D.J. Huber. 2012. Ripening development and quality of melting and nonmelting flesh peach cultivars. HortScience 47:879-885.

Low, S. and S. Vogel. 2011. Direct and intermediated marketing of local foods in the United States. Econ. Res. Rpt. No. ERR-128. 19 Apr. 2013. <http://www. ers.usda.gov/publications/err-economicresearch-report/errl28.aspx>.
Lowenberg-DeBoer, J. 1998. Risk management potential of precision farming technologies. J. Agr. Appl. Econ. 31: 275-285.

Maples, M., K.L. Morgan, M.I. Interis, and A. Harri. 2013. forthcoming. Who buys food directly from producers in the southeastern United States? 23 May 2013. <http://ageconsearch.umn.edu/ bitstream/142929/2/SAEA2013_IP_ Morganetal_AgEcon.pdf $>$.

Mississippi State University. 2009. Policy and procedure statement on human subjects at Mississippi State University. Mississippi State Univ., Office Regulatory Compliance Safety, Res. Policy Ser. OP 79. 03. 23 May 2013. <http://www.msstate. edu/dept/audit/PDF/7903.pdf>.

Morris, A. and R. Muraro. 2008. Economic evaluation of citrus greening management and control strategies, Univ. Florida, Inst. Food Agr. Sci. FE712. 23 May 2013. <http://www.crec.ifas.ufl.edu/extension/ greening/PDF/EconomicEvaluation.pdf>.

Onken, K.A., J.C. Bernard, and J.D. Pesek, Jr. 2011. Comparing willingness to pay for organic, natural, locally grown, and state marketing program promoted foods in the mid-Atlantic region. Agr. Res. Econ. Rev. 40:33-47.

Paxton, K.W., A.K. Mishra, S. Chintawar, R.K. Roberts, J.A. Larson, B.C. English, D.M. Lambert, M.C. Marra, S.L. Larkin, J.M. Reeves, and S.W. Martin. 2011. Intensity of precision agriculture technology adoption by cotton producers. Agr. Res. Econ. Rev. 40:133-144.

Pennings, J.M.E. and P. Garcia. 2001. Measuring producers risk preferences: A global risk-attitude construct. Amer. J. Agr. Econ. 83:993-1009.

Pollack, S.L. 2001. Consumer demand for fruit and vegetables: The U.S. example, p. 49-54. In: A. Regmi (ed.). Changing structure of global food consumption and trade. Mkt. Trade Econ. Div., Econ. Res. Serv., U.S. Dept. Agr., Agr. Trade Rpt. WRS-01-1.

Richards, T.J. 2000. A two-stage model of the demand for specialty crop insurance. J. Agr. Res. Econ. 25:177-194.

Schubert, T. and X. Sun. 2003. Bacterial citrus canker. Florida Dept. Agr. Consumer Serv., Plant Pathol. Circ. 377.

Sherrick, B.J., P.J. Barry, P.N. Ellinger, and G.D. Schnitkey. 2003. Factors influencing farmers' crop insurance decisions. Amer. J. Agr. Econ. 86:103-114.

Shields, D.A. 2012. Federal crop insurance for specialty crops: Background and legislative proposals. Congressional Res. Serv. Rpt. 7-5700. 19 Apr. 2013. <http:// www.nationalaglawcenter.org/assets/crs/ R42813.pdf>.

Thilmany, D., C.A. Bond, and J.K. Bond. 2008. Going local: Exploring consumer behavior and motivations for direct food purchases. Amer. J. Agr. Econ. 90:13031309.

U.S. Department of Agriculture. 2003. Agriculture fact book, 2001-2002. 18 Mar. 2003. <http://www.usda.gov/factbook/ 2002 factbook.pdf>.

U.S. Department of Agriculture. 2007. Census of agriculture. 30 Apr. 2013. <http://www.nass.usda.gov/Statistics_ by_State/Ag_Overview/AgOverview_ FL.pdf>.

U.S. Department of Agriculture. 2012. Fruit and tree nut yearbook spreadsheet files. U.S. Fresh-market fruit imports, monthly, 2011. 23 May 2013. <http:// usda0l.library.cornell.edu/usda/ers / 89022 /Table-H3.xlsx>

U.S. Department of Agriculture. 2013a. Noncitrus fruits and nuts 2012 preliminary summary. 4 Mar. 2013. <http:// usda01.library.cornell.edu/usda/nass/ NoncFruiNu//2010s/2013/NoncFruiNu01-25-2013.pdfs.

U.S. Department of Agriculture. 2013b. Fruit and tree nut yearbook spreadsheet files. Peaches, fresh: Monthly prices received by growers, United States, 1980 to date. 4 Mar. 2013. <http://usda01 library. cornell.edu/usda/ers/89022/Table-B25. $\mathrm{xlsx}>$.

U.S. Department of Agriculture. 2013c. Fruit and tree nut yearbook spreadsheet files. Peaches: Production, utilization, season-average price, U.S., 1980 to date. 4 Mar. 2013. <http://usda0l.library. cornell.edu/usda/ers/89022/TableB24.xlsx>.

Williamson, J.G. and S.A. Sargent. 1999. Postharvest characteristic and consumer acceptance of non-melting peaches. Proc. Florida State Hort. Soc. 112:241-242.

Zepeda, L. and C. Leviten-Reid. 2004. Consumers' views on local food. J. Food Distrib. Res. 35:1-6.

Zepeda, L. and J. Li. 2006. Who buys local food? J. Food Distrib. Res. 37:5-15. 